\title{
Acadian Teacher Identity in Early Twentieth-Century New Brunswick
}

\section{Frances Heylar}

Lakehead University

\section{ABSTRACT:}

This study employs archival documents to trace the awakening Acadian identity of a young New Brunswick teacher during a period in which the province's public school system constituted a program of English language assimilation. Calixte Savoie later became an Acadian activist and Canadian senator; the narrative of his teaching experience illustrates his mounting frustration, culminating in his 1926 resignation in protest after a dispute over French language education rights. The purpose of this paper is to locate Savoie's developing Acadian identity in relation to scholarly research about national identity, including works by Philip Buckner, J.M.S. Careless and Benedict Anderson, and to highlight the history of education in postwar New Brunswick.

RÉSUMÉ:

À l'aide de documents d'archives, cette étude évoque la prise de conscience nationale acadienne d'un jeune enseignant du Nouveau-Brunswick à l'époque où le système d'instruction publique met en place un programme d'assimilation à la langue anglaise. Calixte Savoie devint plus tard un militant acadien, puis sénateur. Le récit de son expérience d'enseignant expose la montée croissante de sa frustration qui culmine, en 1926, avec sa démission, geste de protestation à la suite d'un conflit autour du droit à l'éducation en français. Dans cet article, nous situons l'évolution du sentiment d'appartenance acadienne de Savoie en lien avec la recherche sur l'identité nationale qui s'appuie, entre autres, sur les travaux de Philip Buckner, J.M.S. Careless, et Benedict Anderson. Nous mettons également l'emphase sur l'histoire de l'éducation au Nouveau-Brunswick pour la période de l'après-guerre.

In April 1916, twenty year old New Brunswick teacher Calixte Savoie wrote to the Chief Superintendent of Education and reported that he was enjoying school life and working "for the benefit of the children." ${ }^{1}$ What was most notable about the letter was not the news it shared, however, it was the more subtle message it imparted: Savoie Anglicized his surname by signing his letter "Savoy." Nine years later in April 1925, Savoie penned an editorial for a school journal in which he articulated the demands for education by Acadians. In a strongly worded essay he demanded that 


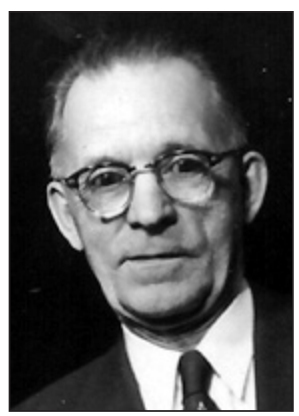

Calixte Savoie

Acadian children should be schooled in their own language. ${ }^{2}$ The difference in attitude toward language represented by these two documents, from an acquiescent acceptance of assimilation to a more militant and self-determined stance, suggests a transformative experience in the development of Acadian national identity.

Calixte Savoie's academic career as student, teacher and principal was intricately tied to the development of his sense of being an Acadian. This research offers a rare glimpse, based on archival evidence and memoir, of life inside New Brunswick classrooms between 1916 and 1926. It adds to our understanding of the history of education in the Maritimes; it also sheds light on the importance of education and the development of linguistic and religious rights of Acadians. This paper presents the argument that a direct causal relationship existed between Savoie's educational experiences and his eventual identification as a leader in the movement for Acadian rights. Further, it shows that Savoie felt he could not continue his fight for equity from within New Brunswick's education system; in order to achieve his goals, he had to leave.

Calixte Savoie was born in 1895 in Bouctouche, a predominantly Acadian area of eastern New Brunswick. ${ }^{3} \mathrm{He}$ attended his village elementary school and completed his studies to Grade 11 at the local convent school. He then attended the Fredericton Normal School twice, once in 1913 to obtain his second class teaching license, and again three years later to upgrade to a first class license. During the intervening time, he taught at a small school near Moncton. It was from this post that he wrote the letter to the Chief Superintendent. He expressed confidence that the school inspector found his work to be more than satisfactory. ${ }^{4}$ When his teacher training was complete, Savoie spent a single year as principal at the Superior School in Edmundston before he was conscripted into the Canadian Expeditionary Forces. ${ }^{5} \mathrm{He}$ did not serve overseas, and upon the resumption of his teaching career, he returned to the Anglophone farming community of Sussex, where he worked first as teacher and then as principal. For his final posting he returned to Edmundston, where he became the principal of the vocational school and took on the additional duty of editing the local school journal. In February 1926, Savoie resigned. He explained the move as a protest against the actions of Anglophone business leaders in Edmundston whom he accused of shutting down the school journal and interfering with local school board elections. Shortly thereafter, Savoie became a businessman, later a Canadian senator and always a leader in the twentieth century effort to bring attention to the rights of Acadians, particularly in terms of educational opportunity. ${ }^{6}$

Any consideration of Savoie's career must be set in context, and the context which is most relevant concerns the nature of national identity in New Brunswick in the early twentieth century. The use of the term "national identity" was complicated because it had meanings that were different for Anglophone and Francophone New Brunswickers. Anglophone citizens exhibited the kind of pan-Canadianism described by Philip Buckner as "multiple identities," in which Canadians thought of themselves 
contemporaneously as both Canadian and British. ${ }^{7}$ This conceptualization of national identity was a legacy of the largely Protestant Loyalists who had formed the backbone of the power elite in New Brunswick since the province's inception in $1785 .{ }^{8}$ The evidence of Calixte Savoie's memoirs as well as other more scholarly studies of Acadians, however, suggests that New Brunswick Francophone national identity rested within a very different framework. ${ }^{9}$ The structure framing Acadian national identity was more accurately delineated by J.M.S. Careless's "limited identities." 10 This is not to say that Acadians did not experience a connection to the pan-Canadian polity. ${ }^{11}$ But New Brunswick's Francophone population identified themselves first as members of the Acadian nation, and this membership had specific characteristics, which were diasporic, land-based, or relating to consciousness and activism. ${ }^{12}$ Diasporic Acadians were those whose ancestors were victims of the 1755 expulsion of French-speaking Roman Catholic inhabitants who never returned to the Maritimes. The land-based Acadians included descendants of the expelled who returned from temporary homes overseas and hid in the forested northern reaches of the province. ${ }^{13}$ The Acadian religion was Roman Catholic and their language was French; Maud Hody's 1964 definition stressed the distinction saying, "Acadian sentiments are based on special attitudes toward the Roman Catholic Church and the French language. . ... [A]n Acadian who has left the Roman Catholic Church is no longer considered an Acadian, and the 'real' Acadian must be of Acadian descent, speak French, and be Catholic in faith." 14 In other words, however it was defined, religion and language were central to Acadians, and their national identity was distinct from the Canadian national identity expressed by Anglophone New Brunswickers. ${ }^{15}$

The stability suggested by Buckner's "long goodbye" and the postwar consensus surrounding New Brunswick's imagined community should be considered in light of the conscription crisis of 1917, which had a noticeable impact on New Brunswick in the years during and after the Great War. Acadians supported the war at its outset. Indeed, they enlisted in numbers proportionately comparable to their Anglophone counterparts. Acadian men either joined English language battalions, or the 165ème Acadian battalion, the members of which were dispersed into Anglophone or Québecois battalions upon their arrival overseas. ${ }^{16}$ This practice of dispersal resulted in Acadian resistance to fighting alongside Anglophones "who did not share - or respect, it must be said — one's language and culture. .." ${ }^{17}$ But as Andrew Theobald explains in his study of conscription in New Brunswick, the level of Acadian enlistment pre-conscription was achieved in spite of a number of factors mitigating against it, most significantly "the English, and also the very limited French language recruiting programmes in New Brunswick [which] ignored the Acadians," and widespread anti-Acadian rhetoric, which reached its zenith during the election campaign of 1917. Theobald further explains that the crisis was a particularly difficult time for the province's Acadian population. The Acadian elite supported the passage of the Military Service Act, while the general population did not, due to the fact that the majority of Acadian men toiled as labourers, farmers or fishermen. The absence of these men from their work would leave their families in difficult financial straits, and might jeopardize their ability to take up the work again at war's end. ${ }^{18}$ The Chief 
Superintendent's correspondence records indicate that this was also a concern for New Brunswick teachers, Calixte Savoie included. ${ }^{19}$ Acadian opposition to conscription was commensurable to the opposition of their Anglophone counterparts, but was interpreted in the public discourse as arising not from their occupation, but from their language and religion. ${ }^{20}$ The immediate result of the conscription crisis in New Brunswick was a political schism, with Acadians throwing their support behind the losing Liberals in the federal election of 1917, and the deepening of Acadian ambivalence toward the Anglophone polity, which simmered below the surface. ${ }^{21}$ This situation indicated that in contrast to the official rhetoric of solidarity and national consensus which was essentially Anglophone and Protestant, religious and linguistic lines divided New Brunswick just as they did Canada, and Acadians, like their Québecois counterparts, imagined a nation different from the Anglophone population. ${ }^{22}$

Calixte Savoie's experiences must also be considered within the context of the history of education in New Brunswick. Religion and language were central elements, even after the creation of the non-denominational system of common schools in 1871. The development of free schools in New Brunswick was a long process, in part because successive provincial governments in the late nineteenth century had to contend with other pressing issues, including the railway industry, Maritime Union and Confederation. ${ }^{23}$ By the end of the century, education officials congratulated themselves on the growing numbers of children in school, but the increase was limited to ten of fourteen counties, and most of the ten had predominantly Anglophone populations. ${ }^{24}$ Such discrepancies in school attendance by county were a recurring feature of education in New Brunswick until the 1960s. ${ }^{25}$

Another obstacle to the establishment of common schools in New Brunswick was the lack of agreement between religious denominations as to the form those schools should take, how teachers should be trained and what teaching materials should be allowed. ${ }^{26}$ The main participants in the debates were the Protestant Loyalists and the Roman Catholics, both Acadian French and Irish Anglophone. Before the advent of common schooling, each denomination had been permitted to run its own schools. With the change in school law, the resulting system of education was perceived by the Acadians to restrict their religious practices, and the outcome was a "social explosion." 27

Shortly after the passage of the Common School Act in 1871, New Brunswick's Roman Catholics prevailed upon the federal government to declare the Act unconstitutional because of the lack of religious freedom it afforded them. In her detailed study of the history of New Brunswick education, MacNaughton described what was at stake, noting that the Roman Catholics "were faced with the necessity of paying taxes for schools to which they could not send their children unless they disobeyed their clergy." 28 The dispute culminated in an 1875 riot in Caraquet during which two men died. ${ }^{29}$ In the aftermath, school officials and legislators struck a so-called “Compromise." While New Brunswick's schools would remain non-denominational, in larger centres, Roman Catholic children would be grouped together in one or several schools. The certificates of teachers trained in Roman Catholic teaching orders would be recognized as substitutes for Normal School graduation diplomas, although 
those teachers would still be required to write a licensing examination. The Board of Education would be responsible for the adoption of textbooks, but "it would be the aim of the educational authorities to render the textbooks suitable for all." 30 While its measures addressed the Acadians' immediate concerns, the "Compromise" did not end the dissension, and fifteen years later a smaller controversy erupted. In this instance in the late 1890s, tension between Protestant and Roman Catholic ratepayers broke out in northern New Brunswick over accusations that the Board of Education had made "secret' regulations favoring religious teaching orders." 31 The result was the modification and clarification of the rules of the "Compromise," including the edict that only the Lord's Prayer and no other prayer could be used in opening exercises. Scripture was to be read from either the King James (Protestant) or the Douay (Anglophone Catholic) version of the Bible. ${ }^{32}$ At the same time, in order to appease the Roman Catholics, religious instruction was ruled permissible at the end of the school day. The result was that by the early 1920s, seven French-speaking religious orders were teaching in New Brunswick's bilingual schools, and many of the licensed teachers in Acadian districts were Roman Catholic teaching sisters. ${ }^{33}$ Historians note that the "Compromise" "mollified opposition to non-sectarian provisos in the 1871 Act," but it "effectively ignored language as a factor." ${ }^{4}$ This observation demonstrates the complexity of education in New Brunswick, where language and religion were so closely linked.

New Brunswick's provincial educational infrastructure was intended for all of the province's population, Anglophone and Francophone, Protestant and Roman Catholic. The province's political elite periodically trumpeted the accomplishments of Acadian students, as in 1889 when the provincial premier noted in an Ottawa speech that "It goes without saying that French and English are equally taught in the schools. The French are anxious that their children learn English. They know that it is in their own interest to acquire this knowledge. . Our people are not afraid of French domination - the children of Acadian parents learn to read and write their own language in our public schools." 35 But the principles of the elite did not necessarily constitute practice, and educational opportunities for French-speaking students still fell short of those available to English-speaking students. In the early twentieth century, New Brunswick schools had at their core a specific ethos which reflected an imagined community, and that community was Anglophone. ${ }^{36}$ Thus, Chief Superintendent Carter worked until his death in 1931 to maintain an administration which provided the infrastructure to support that particular imagined community, the boundaries of which were both Christian and English. ${ }^{37}$ Within his administrative practice, Carter was concerned with normalized notions of national identity, and in this way, his task was the same one that Bruce Curtis ascribes to nineteenth century administrators in Lower Canada, "to configure relations and conditions of association in the promotion of national solidarities." ${ }^{38}$ The difficulty of the task was compounded in Lower Canada and New Brunswick alike by the complex interplay within the population of English, French, Protestant and Catholic citizens. Carter carried out his mission in a variety of ways. For example, he interpreted the Manual of the School Law at the request of school trustees, teachers and others who 
were having difficulty understanding its intricacies. ${ }^{39} \mathrm{He}$ oversaw the appointment of teachers to the Normal School and school inspectors to the various districts across the province; his challenges regarding the appointment of school inspectors had mostly to do with replacing retiring inspectors with candidates drawn from the ranks of New Brunswick's school teachers. ${ }^{40}$ Carter also monitored the licensing of teachers including those Acadians whose lack of fluency in English was a cause of constant concern. In fact, he was regularly required to revisit the licensing requirements of Acadian teachers, as there were never enough fully qualified teachers to work in the bilingual schools. As a result, teachers working on special local licenses were commonplace. ${ }^{41}$

Historians have argued that economic and cultural differences between Anglophone Protestants and Acadians resulted in different valuing of literacy in particular and education more generally. Hody explained that "the Acadians, returning from exile [after 1755], were scattered in tiny parishes throughout the northern counties," and traditionally, Acadian children were prepared for life on the farm and in the home, and had little need for literacy. Acadians also strongly desired that education be denominational. Writing in the early 1960s, Hody added that "Although Acadian children have been attending neutral schools in New Brunswick for nearly a hundred years, the Acadians still hope to have an Acadian school system, French and Catholic, for their children. They consider a neutral school Protestant in its nature, but attack the public school mainly on the grounds of its lack of all religion." ${ }^{42}$ Meanwhile, she added, the Protestant faith of the Loyalist population emphasized Bible reading, which demanded literacy. The result from the start was a province with an ethos valuing educational achievement, including plans for a system of schools. ${ }^{43}$ But evidence suggests that in spite of early indications of Acadian apathy toward education, by the late nineteenth century, apathy had been replaced by determination. ${ }^{44}$ By then, New Brunswick's Acadian population was "growing steadily in numbers, importance, and national consciousness." 45 This trend continued into the twentieth century, and education was viewed as important to the maintenance of their national identity, with the notion that " $[\mathrm{t}]$ he greatest guarantee for the preservation of the French language (and in the Acadians' view, their religion) came through the schools." 46

Pan-Canadian national solidarity as it existed in New Brunswick was clearly tenuous; the conscription crisis of 1917 hinted at its fragile state, and the re-emergence of Acadian nationalism starting in 1925 was confirmation. Carter administered an educational system in which inequities based on language abounded. The Manual of the School Law was available only in English, and letters to the provincial Board of Education written in French received English language responses, particularly because no one at the Board of Education office spoke French. ${ }^{47}$ As Carter explained to his Manitoba counterpart in 1915, French was the only language other than English to be recognized in New Brunswick schools, and then only in Acadian districts. English was required to be taught in all schools, and "Our Law and Regulations contain no provision for the teaching of French in any of the schools," however, "some concessions are given the French in the Primary grades, it being felt that the difficulties of acquiring knowledge, added to the difficulty of acquiring a new language, are too great for children just starting at school." ${ }^{48}$ No schools were monolingually French. 
Instead, as Maud Hody's study explained, public schools were either English or bilingual, and "The French Department at the Normal School had the sole purpose of improving the English of Acadian student teachers sufficiently to enable them to follow the English course." ${ }^{\prime 9}$ Elementary students received instruction in French up until Grade 3, but after that, while the teacher may have spoken French, all textbooks were written in English. ${ }^{50}$ The national identity embodied in New Brunswick's history textbooks, at whatever level, was essentially Canadian and British, although in reality more British than Canadian. Even the province's only French language history textbook was actually a bilingual history textbook, an artifact with assimilative purposes. ${ }^{51}$ Those Francophone students, moreover, who wanted to pursue a secondary education in French could leave the public system to attend private colleges, within the province or elsewhere. In practice, this is where many of New Brunswick's Anglophone and Francophone Roman Catholics including future priests and nuns received their secondary education..$^{52}$

If Acadians felt they had a just cause, in some cases it was because they felt stymied by educational officials. The Chief Superintendent himself expressed incredulity at the inability of Acadians to understand English, responding to one 1918 request for a French version of Manual of the School Law writing, "It is somewhat surprising to me that after some forty years of School Law, and the teaching of English in the schools, that there are people in your district who cannot read [the English version]." ${ }^{53}$ Calixte Savoie's memoirs reported an incident in the 1920s when he overheard an unidentified school administrator (but one whose voice he says he thought he recognized) in a private moment say of Acadians, "It is by keeping them ignorant that we are best able to dominate them. Allow them to teach themselves and you place in their hands the most powerful weapon to wean themselves from their cultural and economic poverty."'54

Throughout Calixte Savoie's career in education, he encountered numerous barriers to his progress, sometimes based on his French language, sometimes on his Roman Catholicism. It took time before he recognized the barriers as systemic, and he remained within the public system as he moved through his roles as student, as teacher and finally as principal. In the beginning, Savoie was full of hope and ambition. His memoir describes his secondary school studies, with long hours of the night spent memorizing English language textbooks. Although Savoie did not refer to the development of his mastery of the English language, it is likely that this is where it began, and he characterized the effort required as "superhuman." ${ }^{5} \mathrm{He}$ reported that after Grade Eight he was the only Acadian in the class, and acknowledged that as a student he blamed this situation on a lack of intelligence among his peers. ${ }^{56}$ Savoie must have been proficient enough in English for him to succeed at Normal School and attain a second class license, a rare achievement among Acadian teachers. ${ }^{57}$ In his early years as a teacher, his Acadian identity was nascent, as evidenced by the alteration of his surname in his early letter to the Chief Superintendent. ${ }^{58}$ This communication was not the work of an Acadian nationalist.

The tone of the 1916 letter to the Chief Superintendent suggested that the two men were on friendly terms, but Savoie's memoirs and the archival records indicate 
a far more complicated relationship. The first hint of difficulty came with an incident which Savoie said he recounted specifically because it was the first of a series of skirmishes, and because it helped him to understand the attitude of the government toward the education and the rights of Acadians. ${ }^{59}$ The local priest made his pastoral visit to Savoie's St. Anselme school, and in preparation for the event, the young teacher instructed his Anglophone Protestant students that they were not required to kneel before the curate. In order to save them from embarrassment, he also provided each Anglophone Protestant student with a ten cent coin for the blessing. The visit went off without a hitch. Ten days later, Savoie received a letter from Carter admonishing him for breaking school law by inviting a priest to his classroom and requiring all students to kneel. Savoie was ordered to explain his conduct or risk losing his teaching license. On the advice of his priest, Savoie threatened to go to the newspapers, and Carter backed down. Savoie characterized this metaphorically as a victory in the first round of a boxing match against educational authorities, and his narration noted that this incident marked his first awareness of Anglophone use of intimidation. ${ }^{60}$ The education of Calixte Savoie into the intricacies of religious and linguistic tensions in New Brunswick had begun in earnest.

A complimentary note in the Superintendent's Annual Report for 1916-1917 praised Savoie for stepping in at the provincial Normal School to replace an ailing French language instructor. ${ }^{61}$ Savoie's memoirs tell a strikingly different tale, in which he was recruited to teach the French courses for three months while continuing his own studies. After the fact he asserted that the decision to take on the extra duties would profit him in his later efforts to improve schooling in New Brunswick, but at the time he received no pay for his services. When he approached the Chief Superintendent regarding this injustice, Carter indicated that as a student, Savoie was not entitled to a salary. Still, Carter offered to pay him twenty-five dollars. Savoie accused Carter of bribing him, and threatened to go to the provincial SecretaryTreasurer. Shortly thereafter, he received a sizeable cheque. ${ }^{62}$ The second round was Savoie's, and in spite of these setbacks, he continued to distinguish himself. During the 1917-1918 school year he took first prize in physical training and military drill for graded schools. ${ }^{63}$

With his 1917 arrival to teach at the Superior School in the northwestern New Brunswick town of Edmundston, Savoie became immersed in a community different from any he had encountered in the southeast. Madawaska County was home to more Québécois than Acadians. ${ }^{64}$ He reported in his memoirs that only a few families spoke English, and that the French population consisted of people of Acadian, French-Canadian or Franco-American descent. This resulted in a distinct identity: the only acceptable collective name was Madawaskaien. ${ }^{65}$ Savoie soon came under the wing of Albert Sormany, a local doctor who had already established himself as a strong Acadian nationalist. Madawaska became the starting place for a thirty-year association between the two men. During this time they lobbied to change the status of New Brunswick's Acadian population. ${ }^{66}$ Savoie received a hint of the struggle ahead in the form of an encounter with Carter in Fredericton in the early days of his new position in Edmundston. Carter asked Savoie whether he was enjoying the 
community, and when Savoie responded positively, Carter commented in English that he thought Madawaskaiens were "the worst bunch of law breakers we have in New Brunswick." ${ }^{67}$

Although he would return years later for a second soujourn notable for its dramatic events, Calixte Savoie's first stay in Edmundston was brief. The introduction of conscription in Canada in 1917 served to interrupt his teaching career, and this interlude provided another illustration of Savoie's character and the complexity of French-English relations in New Brunswick. Savoie's attestation papers showed that he was drafted under the Military Service Act of 1917 . He was twenty-two at the time, and was deemed fit for service overseas. ${ }^{68}$ His memoirs were explicit about his military service as a significant event in his life, but made no reference to the conscription crisis as his reason for enlisting. Instead, Savoie briefly described his experience as a soldier during the last few months of the war. Like many other conscriptees, he never saw active service. ${ }^{69}$ No sooner did he arrive at winter quarters in Saint John than he was quarantined as part of the Spanish flu epidemic of 1918. Meanwhile, his new bride fell ill, and he left the barracks without permission to be at her side in Sussex. Upon his return to his company, but before his case could be decided, he too fell ill and was sick enough to be given the last rites in hospital. He recovered within ten days, however, and left the hospital on Armistice Day, November $11^{\text {th }}$. By then, Savoie's main goal was to resume his teaching career, but the details of his successor's contract at the school in Edmundston meant that unless Savoie was released from the army in time for classes to begin in January, he would be unable to teach until the following September. Such a long period of unemployment worried him. His request to the commander for early release went unanswered, so Savoie wrote to the Minister of Militia and Defense Sam Hughes in Ottawa, who left the final arbitration about his fate to his company commander. Once again, Savoie's gambit paid off, and he was released from his military duties in order to find a teaching position for January 1919. This incident provided further evidence of Savoie's penchant for risk-taking. When he felt strongly enough about a cause, he was willing to confront authority in order to achieve his goal.

But Savoie did not return immediately to Edmundston. His first post-military service position was as a teacher and later the principal in an Anglophone school in Sussex, where he and his wife made up two-thirds of the town's French-speaking population. ${ }^{70}$ The fact that he was interviewed and then awarded the position in an English-only school was testament to his mastery of the language. His French Catholic identity was directly addressed during the interview process, however, and he reported in his memoirs his confident response to the questioning of the local school board members who asked how he would deal with students who might use his language and religion to take advantage of him. He responded that he had no fear on that score. ${ }^{71}$ But the apparently fearless Savoie soon faced a challenge precisely because of his religion. The Sussex school board required him to lead an assembly in front of the gathered school population every Monday morning. Each meeting closed with a recitation of the Lord's Prayer and a rendition of "God Save the King." In addition, the board ordered Principal Savoie to read from the Bible as 
part of the proceedings. But the Bible was a Protestant one, and the tenets of Roman Catholicism did not permit him to read from a Protestant Bible. Over the next few weeks, Savoie proposed a number of solutions to the problem, all of which were rejected by the school board, until finally the young principal proffered his resignation. The school board met with him the next day and withdrew all demands, permitting him to read passages from his own Bible.

At no time did Savoie approach the Chief Superintendent about this problem. Had he done so, Carter could have advised him that according to the school law, either the Protestant or the Douay (Roman Catholic) Bible were permissible for school readings. ${ }^{72}$ It is unclear whether Savoie had read the Manual of the School Law by then, a volume that was still available only in English. His failure to contact Carter might be another indication that their relationship, subject to many highs and lows, was by then at a particularly low ebb. Savoie wryly noted that once the incident was closed, religion was never to him mentioned again in Sussex, except when the local Presbyterian minister congratulated him on standing his ground. He acknowledged the experience as another turning point in his career, and called his four years in an Anglophone school an extremely useful lesson in how the Anglophone mind worked. ${ }^{73}$

The administrative record provided a more positive image of Savoie's standing with the Board of Education and the Chief Superintendent. Correspondence indicated that in 1920 Carter offered Savoie the permanent position of French language Normal School instructor when the ailing incumbent finally retired. Savoie declined to accept, citing the higher salary of a principal, and the lower cost of living outside of the provincial capital. His third reason was that "a young man has to look forward for his own ambitions." 74 This vote of confidence from Carter suggested that he agreed Savoie had a bright future as an educator, but Savoie did not report the offer in his memoirs. The discrepancy serves to highlight the general absence in the administrative record of information that reflected negatively on Savoie, and to exemplify Savoie's tendency to focus his own narrative on confrontation in order to maintain a consistent theme of antagonism.

If Savoie sought confrontation, his second period of employment in Edmundston brought him plenty. He explained in his memoirs his reasons for returning to the northwest, which were primarily in order to raise his children in a francophone environment, and because of a sense of obligation to his Acadian community. Savoie claimed that by then he had seen enough of the crippling effect of New Brunswick education upon the French language and culture, and he felt ready to join the struggle for Acadian educational rights. ${ }^{75}$ At the instigation of Savoie's old friend Albert Sormany, a group of local men formed a weekly study group to investigate strategies for improving education. Along with Sormany and Savoie, the collective eventually included the editor and an employee of the local newspaper Le Madawaska, the director of the business school, a Canadian National Railway office worker, a priest and a single blue collar worker. The group was christened "La Petite Boutique." Among the members' main projects was the creation of a bilingual newspaper titled Le Madawaskaien. It was published out of Savoie's school and contained articles critical of New Brunswick education, stories which were sometimes reprinted 
in newspapers with broader distribution such as the regional Le Madawaska and Moncton's LÉvangéline. The articles also caught the attention of the Language and Education Committee of la Société nationale l'Assomption, the Acadian life insurance company. ${ }^{76}$ The intended audience of the essays was first and foremost the Acadian population, but Savoie did not ignore New Brunswick's Anglophones or pan-national identity entirely. For example, Savoie's memoirs described an article in Le Madawaskaien which had the express purpose of easing Anglophone fears about Acadians, and which contained a rare but strategic reference to Canada. It stressed the importance of developing understanding among Canadians and proposed that by frankly stating their needs, Acadians contributed to national unity. ${ }^{77}$ This argument exemplified a calculated approach in order to engage a bilingual audience, and this use of careful strategizing was typical of the activities of La Petit Boutique.

As his next major project, in December 1924 Savoie undertook the leadership of the first ever Madawaska County Teachers' Institute. The resolutions arising from the meeting constituted an explicit articulation of the demands of Acadians concerning education. They provided a list of justifications, including the overall provincial illiteracy rate of 12.46 per cent, and the lack of required examinations in French grammar and literature for licensing of teachers. Among the proposed solutions were the remodeling of the course of instruction in public schools and Normal Schools, and the provision of textbooks in French. ${ }^{78}$ The first Teachers' Institute was so successful that another was held the following year. This time the resolutions passed concerned school readers and the geography textbook. The major concern, however, was the Manual of the School Law. Citing the fact that the population of Madawaska was ninety-eight per cent French speaking and that few of the trustees or ratepayers could interpret the law because it was written in English, the teachers resolved that a French translation should be created. ${ }^{79}$ The meeting received attention from LÉvangéline, the major Acadian newspaper for the province. A front page editorial focused on a presentation by two English teachers from Savoie's school who issued a challenge to New Brunswick's Acadians saying, "'It is up to you French people to get more French taught in your lower grades. You cannot expect those who rule to give you what you do not ask or fight for.'” 80

Even as preparations were underway for the 1925 Teachers' Institute, Savoie and the Chief Superintendent worked closely together on another project. Savoie's correspondence noted his concern about the low number of French-speaking students attending Normal School for their first class license, and recorded Carter's suggestion that he draft a resolution to put to the Board of Education in order to address the problem. ${ }^{81}$ Carter was generous in his advice, recommending the form and substance of the proposed resolution. ${ }^{82}$ Savoie expressed his appreciation saying, "I shall always feel indebted to you for the great interest you have shown in this connection." ${ }^{33}$ As far as the official record is concerned, however, this letter marked the end of any positive feelings between Savoie and Carter while the former was an employee of the New Brunswick school system.

Savoie's memoirs indicated that by the summer of 1925 Anglo-Acadian relations in Madawaska had deteriorated, largely due to the presence and political influence 
of the Fraser Pulp Mill and its Anglophone executives. His bilingual newspaper, Le Madawaskaien, was shut down in June by the school board under pressure from the mill bosses and local Anglophone politicians. ${ }^{84}$ In addition, when one of the Acadian school board members moved away, the voters chose to replace him with a board member sympathetic with the town's Anglophone elite. Savoie expressed his disillusionment accusing the local workers, ninety per cent of whom were Francophones, of submitting to the influence of their Anglophone bosses. ${ }^{85}$

At the same time, Savoie's memoirs briefly mentioned difficulties among the teaching staff at the Edmundston school, created by an Anglophone school board member. The nature of these difficulties is unclear, but they may have been related to an issue noted in Carter's correspondence. In mid-September 1925 Carter requested clarification from one Edmundston instructor regarding her teaching assignment. Her response described a situation in which teachers at the school taught in both the Academic and Vocational departments at and below the secondary school level. ${ }^{86}$ In terms of the organization of New Brunswick's educational structure, the Academic and Vocational panel were separate departments, directed by different superintendents and independent of each other. ${ }^{87}$ Teachers were not permitted to cross departments. The Edmundston arrangement, according to Carter, represented a "great mixup," and a violation of the terms of the teachers' licenses. The change had been made without consultation with the New Brunswick Board of Education, and Carter's frustration was reflected when he wrote to the teacher saying, "It is impossible for me to unravel this state of affairs until I have more information." 88

Part of Carter's attempt to "unravel the state of affairs" was to query Savoie. The tone of the correspondence reflected a sharp decline in collegiality between the two men. Savoie's response was insistent: "You must understand Dr. Carter that there is no overlapping in the sense that you take it and if we change classes for certain subjects it is because we feel that such a change is for the good of the school." The principal saw his actions, although in violation of the rules, as a benefit to Acadian students. He continued, "It is only within the last three or four years that we have been able to do effective work in our school, and if for the sake of one or two individuals we are forced to return to the old traditional ways of doing things, in half or not at all, it is time for the people of this province to open their eyes and see where we are drifting to - in as far as educational matters are concerned. I feel that it would be a great error, yes, an injustice that to endeavor [sic] to confine the work of a teacher to a special grade. Why should we not have experts for the different subjects, if we can do so with the same money?" 89

Carter took great offence at Savoie's reply, marking the lowest point in their ten year correspondence. He underlined several passages in the letter, and those are the particular points he addressed in his response. Carter explained that a request for information had been sent to all school principals, not just to Savoie, and instructed him that if teachers taught in subjects for which they were not licensed, "chaos would be the result." He closed his letter saying, "I refuse to be intimidated in the discharge of my duties. These statements are both unjustified and uncalled for." ${ }^{0}$ The reference in Savoie's memoirs to difficulties among the teaching staff may have alluded to this 
incident. He did remark that maintaining a positive atmosphere among the faculty and avoiding internal discipline problems was important in achieving the goal of improving Acadian education. ${ }^{91}$ It is unclear whether this controversy or the more public problem with the school board election was the catalyst, but Savoie and four other members of his teaching staff submitted letters of resignation effective June 1926. As far as Savoie was concerned, the difficulty lay with the educational system. In his opinion, New Brunswick's schools had a disastrous effect not just on Acadians but on the entire population of the province, because the quality of a society was only as good as the quality of its members. ${ }^{92}$

Calixte Savoie's resignation was more of a beginning than an ending. In the ensuing years, he became a passionate public voice for Acadian education. Even though his employment as a teacher and principal was about to draw to a close, at the end of June 1926 he was still called upon to speak about bilingual education to a teachers' conference. ${ }^{93}$ His next position was short-lived: as a regional sales manager for the World Book Encyclopedia his salary was larger than his principal's take home pay. ${ }^{94}$ Savoie was soon appointed general manager and secretary treasurer of the same Acadian organization which had paid attention to his articles in Le Madawaskaien, la Société L'Assomption. ${ }^{95}$ From that vantage point he was instrumental in making Acadian education an important public issue in New Brunswick. The province's system of teacher education was a major focus of his reform efforts. Savoie was particularly concerned with the fact that although Acadians comprised over thirty per cent of New Brunswick's population, far fewer than thirty per cent of Normal School students were Acadian. ${ }^{96}$ By the late 1920 s, their relationship apparently repaired, Carter took up Savoie's proposal that teachers destined for French language schools should be required to pass examinations in French grammar and composition. ${ }^{97}$ Late in the decade such reforms were scuttled as a result of protests from Anglophone interests in the province. ${ }^{98}$ In the meantime Savoie continued to press educational authorities on the issues, published pamphlets to gain support from the Acadian population, served as the editor of the newspaper LÉvangéline, became a founding member of the Association of Acadian Education, and in 1955, an independent Liberal member of the Canadian Senate. ${ }^{99}$ The fight for equity in education was a long one, however, and it was not until the Byrne Commission of 1963, the Equal Opportunities Act of 1967 , and a wholesale change in the system of municipal taxation that the longneeded changes to education were finally enacted which would transform schooling for Acadian students. ${ }^{100}$

Throughout his teaching career, Calixte Savoie found himself in constant conflict with those who led the education system in New Brunswick, largely because he recognized and was vocal in protesting the inequities suffered by Acadian children. He was not afraid of controversy, and repeatedly confronted officials who stood in the way of the achievement of his goal to bring justice and fairness to New Brunswick education. Savoie's experience in schools, from the long nights as a student he spent memorizing passages from his English language textbooks, through his fight as a principal over Bible readings in an Anglophone Protestant community, to his call for a French language Manual of the School Law, all helped to shape his Acadian identity 
and propelled him to make an early exit from his teaching career after only thirteen years. The insider's knowledge he gained during his time as an educator would serve him well for the rest of his life, and gave him the tools he needed in order to become a leader in the movement to improve Acadian education in New Brunswick.

\section{Notes}

1 Provincial Archives of New Brunswick (PANB), RS116 B8q4b, Savoy to Carter, 4 Apr. 1916.

2 Calixte F. Savoie, Memoires d'un Nationaliste Acadien (Moncton: Editions d'Acadie, 1979), 93.

3 Andrew Theobald, "We'll Never Let the Old Flag Fall': The Conscription Crisis in New Brunswick During the First World War" (M.A. Thesis, University of New Brunswick, 2000), 236.

4 Savoy.

5 "Attestation of Calixte Savoie," Library and Archives Canada, http://www. collectionscanada.gc.ca/databases/cef/001042-119.01-e.php?\&id_nbr=215284\&interva l=20\&\&PHPSESSID=jqoo5usidn6gov6k8v86jrior1

6 Savoie, Memoires d'un Nationaliste Acadien, Richard Wilbur, The Rise of French New Brunswick (Halifax: Formac Press, 1989).

$7 \quad$ Phillip Buckner, "The Long Goodbye: English Canadians and the British World," in Rediscovering the British World, ed. Phillip Buckner and R. Douglas Francis (Calgary: University of Calgary Press, 2005).

8 Desmond Morton, A Short History of Canada, 5th ed. (Toronto: McClelland \& Stewart, 2001).

9 Savoie, Memoires d'un Nationaliste Acadien, Neil J. Boucher, "Acadian Nationalism and the Episcopacy of Msgr. Edouard-Alfred Leblanc, Bishop of Saint John, New Brunswick (1912-1935): A Maritime Chapter of Canadian Ethno-Religious History" (Ph.D. Diss., Dartmouth University, 1992), John Mack Faragher, A Great and Noble Scheme: The Tragic Story of the Expulsion of the French Acadians from Their American Homeland (New York: W.W. Norton \& Company, Inc., 2005), Naomi Griffiths, "Acadians," in Encyclopedia of Canada's Peoples, 114-136, ed. Paul R. Magocsi (University of Toronto Press: 1999).

10 J.M.S. Careless, "Limited Identities' in Canada," Canadian Historical Review L, no. 1 (1969), and 'Limited Identities - Ten Years Later," Manitoba History, no. 1 (1981), http://www.mhs.mb.ca/docs/mb_history/01/limitedidentities-.shtml.

11 See Colin M. Coates, "French Canadians' Ambivalence to the British Empire," in Canada and the British Empire, 181-199, ed. Phillip A. Buckner (Oxford/Toronto: Oxford University Press, 2008), and Patrice A. Dutil, "Against Isolationism: Napoléon Belcourt, French Canada, and 'La Grande Guerre'," in Canada and the First World War: Essays in Honour of Robert Craig Brown, 96-137, ed. David MacKenzie (Toronto: University of Toronto Press, 2005).

12 James Laxer, The Acadians: In Search of a Homeland (Toronto: Doubleday Canada, 2006), 6-7.

13 The largest number of land-based Acadians lived in New Brunswick. 1921 census figures indicate that 10 per cent of New Brunswickers were monolingually French. In contrast, the population of French-only speakers was less than one per cent in Prince Edward Island and just over one per cent in Nova Scotia. See Department of Trade and Commerce, Sixth Census of Canada, 1921, vol. II. Population. (Ottawa: Dominion of Canada. Dominion Bureau of Statistics, 1925). The legacy of the "Grande 
Dérangement" provided the single most important factor distinguishing the Acadians from their Francophone counterparts in Québec. For more on the history of the Acadians, see Faragher, A Great and Noble Scheme: The Tragic Story of the Expulsion of the French Acadians from Their American Homeland, Griffiths, "Acadians," 114-136, and Wilbur, The Rise of French New Brunswick.

14 Maud Hazel Hody, "The Development of the Bilingual Schools of New Brunswick" (Ed.D. Dissertation, University of Toronto, 1964), 18-19.

15 For more on the centrality of religion and language to Aca dian national identity, see Boucher, "Acadian Nationalism and the Episcopacy of Msgr. Edouard-Alfred Leblanc, Bishop of Saint John, New Brunswick (1912-1935): A Maritime Chapter of Canadian Ethno-Religious History," Coates, "French Canadians' Ambivalence to the British Empire," 181-199, and Griffiths, "Acadians," 114-136.

16 Ian McKay, "The 1910's: The Stillborn Triumph of Progressive Reform," in The Atlantic Provinces in Confederation, 192-229, ed. E.R. Forbes and D.A. Muise (Toronto: University of Toronto Press, 1993), and Theobald, “'We'll Never Let the Old Flag Fall': The Conscription Crisis in New Brunswick During the First World War."

17 Dutil, "Against Isolationism: Napoléon Belcourt, French Canada, and 'La Grande Guerre,", 118.

18 Theobald, "We'll Never Let the Old Flag Fall': The Conscription Crisis in New Brunswick During the First World War," 151-52.

19 See PANB, Correspondence of the Chief Superintendent. World Wars, RS116 B2t1, Savoie to Carter, 30 Nov. 1918, and PANB, RS116 B8k4, Jones to Carter and Clark, 8 Sept. 1914.

20 Theobald, "We'll Never Let the Old Flag Fall': The Conscription Crisis in New Brunswick During the First World War".

21 See Hody, "The Development of the Bilingual Schools of New Brunswick," and Dutil, "Against Isolationism: Napoléon Belcourt, French Canada, and 'La Grande Guerre'." David MacKenzie and Colin Coates describe the 1917 federal election in David MacKenzie, "Eastern Approaches: Maritime Canada and Newfoundland," in Canada and the First World War: Essays in Honour of Robert Craig Brown, 350-376, ed. David MacKenzie (Toronto: University of Toronto Press, 2005), and Coates, "French Canadians' Ambivalence to the British Empire," 181-199. The Union party under Robert Borden won the election and formed the federal government.

22 Morton, A Short History of Canada.

23 Katherine F. MacNaughton, The Development of the Theory and Practice of Education in New Brunswick, 1784-1900; a Study in Historical Background (Fredericton: The University of New Brunswick, 1947).

24 Ibid.

25 Clay Merrithew, "The Educational Reforms of the Programme of Equal Opportunity (New Brunswick)" (M.Ed. Thesis, University of New Brunswick, 1995). With the administration of Louis J. Robichaud, the province's first elected Acadian Premier, came the introduction of the Equal Opportunities Act, a wide-ranging series of legislative changes designed to divide the provision of services more equitably between $\mathrm{New}$ Brunswick's Anglophone and Francophone population.

26 See Paul Axelrod, The Promise of Schooling: Education in Canada, 1800-1914 (Toronto: University of Toronto Press, 1997).

27 Laxer, The Acadians: In Search of a Homeland, 135.

28 MacNaughton, The Development of the Theory and Practice of Education in New Brunswick, 1784-1900; a Study in Historical Background, 202. See also Axelrod, The Promise of Schooling: Education in Canada, 1800-1914.

29 Laxer, The Acadians: In Search of a Homeland, MacNaughton, The Development of the Theory and Practice of Education in New Brunswick, 1784-1900; a Study in Historical Background, and Wilbur, The Rise of French New Brunswick. 
30 MacNaughton, The Development of the Theory and Practice of Education in New Brunswick, 1784-1900; a Study in Historical Background, 220.

31 Ibid., 224.

32 New Brunswick, Manual of the School Law of New Brunswick (Fredericton: Province of New Brunswick, 1892).This regulation was also included in the 1913 Manual of the School Law. See Manual of the School Law and Regulations of New Brunswick (Fredericton: Province of New Brunswick, 1913).

33 Hody, "The Development of the Bilingual Schools of New Brunswick". Boucher disagrees that religious leaders did not involve themselves in school affairs, and offers the career of Roman Catholic Bishop LeBlanc as an example. See Boucher, "Acadian Nationalism and the Episcopacy of Msgr. Edouard-Alfred Leblanc, Bishop of Saint John, New Brunswick (1912-1935): A Maritime Chapter of Canadian Ethno-Religious History."

34 Shawna Stairs Quinn, “"Sympathetic and Practical Men”? School Inspectors and New Brunswick's Educational Bureaucracy, 1879-1909” (M.A. Thesis (History), University of New Brunswick, 2006), 53.

35 Honorable A.G. Blair, quoted in Hody, "The Development of the Bilingual Schools of New Brunswick," 344.

36 Benedict Anderson, Imagined Communities: Reflections on the Origin and Spread of Nationalism, Revised ed. (London/New York: Verso, 2006).

37 Stairs Quinn notes that New Brunswick's late nineteenth century school inspectors, including Carter, "commonly cast their patriotic radius slightly short of empire, ... focusing on local heritage and national pride." She adds that Carter had an active interest in local and Loyalist history. Stairs Quinn, "“Sympathetic and Practical Men"? School Inspectors and New Brunswick's Educational Bureaucracy, 1879-1909," 87-88, 210.

38 Bruce Curtis, "State of the Nation or Community of Spirit? Schooling for Civic and Ethnic-Religious Nationalism in Insurrectionary Canada," History of Education Quarterly 43, no. 3 (2003): 328.

39 For an example of Carter's advice regarding school law, see PANB, Correspondence of the Chief Superintendent, RS116 B8b4c, Carter to Waldron, 10 Sept. 1920.

40 See New Brunswick, Annual Report of the Schools of New Brunswick 1919-20, by the Chief Superintendent of Education, ed. Board of Education (Fredericton: Government of New Brunswick, 1921).

41 Annual Report of the Schools of New Brunswick 1911-1912 by the Chief Superintendent of Education, ed. Board of Education (Fredericton: Government of New Brunswick, 1913).

42 Hody, "The Development of the Bilingual Schools of New Brunswick," 123. See also Boucher, "Acadian Nationalism and the Episcopacy of Msgr. Edouard-Alfred Leblanc, Bishop of Saint John, New Brunswick (1912-1935): A Maritime Chapter of Canadian Ethno-Religious History," and MacNaughton, The Development of the Theory and Practice of Education in New Brunswick, 1784-1900; a Study in Historical Background.

43 Hody, "The Development of the Bilingual Schools of New Brunswick," 122-24. See also MacNaughton, The Development of the Theory and Practice of Education in New Brunswick, 1784-1900; a Study in Historical Background.

44 The Caraquet riots which led to the 1875 "Compromise" provided an example of this determination. See MacNaughton, The Development of the Theory and Practice of Education in New Brunswick, 1784-1900; a Study in Historical Background. The riots had their parallel in mid-nineteenth century riots in the eastern townships of Quebec described by Wendie Nelson. Nelson argues convincingly that the troubles arose because "most parents wished to school their children, but objected to compulsion and to taxes deemed to be unjustly burdensome." Wendie Nelson, "'Rage against the Dying 
of Light': Interpreting the Guerre Des Eteignoirs," Canadian Historical Review 81, no. 4 (December, 2000): para. 24.

45 MacNaughton, The Development of the Theory and Practice of Education in New Brunswick, 1784-1900; a Study in Historical Background, 228. Stairs Quinn describes the career of school inspector Valentin Landry, which was cut short in 1886 because of his inability to reconcile his ardent Acadian national identity with the demands of the job. Like Calixte Savoie, Landry had to work to improve the education of Acadian children from outside, not from inside the New Brunswick school system. See Stairs Quinn, “"Sympathetic and Practical Men”? School Inspectors and New Brunswick's Educational Bureaucracy, 1879-1909.”

46 Boucher, "Acadian Nationalism and the Episcopacy of Msgr. Edouard-Alfred Leblanc, Bishop of Saint John, New Brunswick (1912-1935): A Maritime Chapter of Canadian Ethno-Religious History," 227.

47 New Brunswick, Schools Act, PANB, Correspondence of the Chief Superintendent of Education, Language, RS116 B2d, Chief Clerk to Babineau, 16 Dec. 1912; PANB, Correspondence of the Chief Superintendent of Education. Language, RS116 B2d, Chief Clerk to Noil, 3 Sept. 1913.

48 PANB, Correspondence of the Chief Superintendent of Education. Language, RS116 B2d. Carter, to Thornton. 18 Aug. 1915.

49 Hody, "The Development of the Bilingual Schools of New Brunswick," 229.

50 Savoie, Memoires d'un Nationaliste Acadien.

51 Ph. F. Bourgeois, Histoire Elémentaire Du Canada (London: Thomas Nelson et Fils, Ltd., n.d.), and Elementary History of Canada (London: Thomas Nelson and Sons, Ltd., n.d.). This text was actually one volume, with French text on one side of each page, and English on the facing page. In spite of the fact that it was written in English and French, by 1922 Bourgeois' textbook was specifically included on the prescribed list only for the bilingual schools. It was prescribed in New Brunswick from 1914 until 1953. See New Brunswick, Manual of the School Law and Regulations of New Brunswick (Fredericton: Province of New Brunswick, 1922), Hody, "The Development of the Bilingual Schools of New Brunswick."

52 Hody, "The Development of the Bilingual Schools of New Brunswick," MacNaughton, The Development of the Theory and Practice of Education in New Brunswick, 1784-1900; a Study in Historical Background.

53 PANB, RS116 B2d, Correspondence of the Chief Superintendent of Education, Language, Carter, to Michaud, 2 Oct. 1918.

54 Wilbur, The Rise of French New Brunswick, 138. This is the translation of a passage from Savoie, Memoires d'un Nationaliste Acadien, 145. The patronizing sentiments expressed are similar to those reported by Bruce Curtis, that "State school reformers routinely argued that it would be far better to leave the masses completely ignorant than to teach them to read and write without forming their moral character." See Bruce Curtis, Building the Educational State: Canada West, 1836-1871 (London ON: The Althouse Press, 1988), 15.

55 Savoie, Memoires d'un Nationaliste Acadien, 16.

56 Ibid.

57 One school inspector, referring to the dearth of Acadian teachers with anything more than a local license complained, "It does not dawn on the trustees that it would be better to have a trained teacher who speaks no French than to have a local licensed teacher who can speak French, or no teacher at all." See New Brunswick, Annual Report of the Schools of New Brunswick 1914-1915 by the Chief Superintendent of Education, ed. Board of Education (Fredericton: Government of New Brunswick, 1916), 11.

58 Savoy.

59 Savoie, Memoires d'un Nationaliste Acadien, 35.

60 Ibid., 36. 
61 New Brunswick, Annual Report of the Schools of New Brunswick 1916-1917 by the Chief Superintendent of Education, ed. Board of Education (Fredericton: Government of New Brunswick, 1918).

62 Savoie, Memoires d'un Nationaliste Acadien, 44.

63 New Brunswick, Annual Report of the Schools of New Brunswick 1917-1918 by the Chief Superintendent of Education, ed. Board of Education (Fredericton: Government of New Brunswick, 1919).

64 Theobald, "'We'll Never Let the Old Flag Fall': The Conscription Crisis in New Brunswick During the First World War".

65 Savoie, Memoires d'un Nationaliste Acadien.

66 Wilbur, The Rise of French New Brunswick.

67 Savoie, Memoires d'un Nationaliste Acadien, 46.

68 "Soldiers of the First World War CEF: Attestation Papers of Calixte Savoie," ed. Veterans Affairs Canada (Ottawa: Library and Archives Canada, 1918).

69 Theobald, “'We'll Never Let the Old Flag Fall': The Conscription Crisis in New Brunswick During the First World War".

70 Savoie, Memoires d'un Nationaliste Acadien. The school custodian was the remaining third.

71 Ibid., 53.

72 New Brunswick, Schools Act.

73 Savoie, Memoires d'un Nationaliste Acadien.

74 PANB, Correspondence of the Chief Superintendent, RS116 B8f4b, Savoie to Carter, 22 May 1920.

75 Savoie, Memoires d'un Nationaliste Acadien, 71.

76 Alexandre-J. Savoie, "L'enseignement En Acadie De 1604 À 1970," in Les Acadiens Des Maritimes: Études Thematiques, 419-466, ed. Jean Daigle (Moncton: Centre d'études acadiennes, 1980), Wilbur, The Rise of French New Brunswick.

77 Savoie, Memoires d'un Nationaliste Acadien, 92. Richard Wilbur notes that Savoie only quoted this article in his memoirs, but he likely was its author. See Wilbur, The Rise of French New Brunswick.

78 PANB, Records of the Chief Superintendent of Education, RS116 B3a3, Calixte Savoie, "Resolution of the Madawaska County Teachers' Institute," December 1924.

79 PANB, Records of the Chief Superintendent Of Education, RS116 B3a3, Calixte Savoie and Harry Gilmore, "Resolutions of the Madawaska County Teachers' Institute," November 1925.

80 Alfred Roy, “C'est À Nous De Demander [Editorial]," L'Evangeline, November 26, 1925.

81 PANB, Correspondence of the Chief Superintendent of Education. Madawaska County - teachers 1901-1927. B8j4a, Savoie to Carter, 14 Sept. 1925.

82 PANB, Correspondence of the Chief Superintendent of Education. Madawaska County - teachers 1901-1927. B8j4a, Carter to Savoie, 16 Sept. 1925.

83 PANB, Correspondence of the Chief Superintendent of Education. Madawaska County - teachers 1901-1927. B8j4a, Savoie to Carter, 18 Sept. 1925.

84 Wilbur, The Rise of French New Brunswick.

85 Savoie, Memoires d'un Nationaliste Acadien, 102.

86 PANB, Correspondence of the Chief Superintendent of Education. Madawaska County - teachers 1901-1927. B8j4a, Hayes to Carter, 19 Sept. 1925.

87 Eric Duncan MacKenzie, "The Historical Development of the New Brunswick Teachers' Association, 1902-1954” (M.Ed. Thesis, University of New Brunswick, 1971).

88 PANB, Correspondence of the Chief Superintendent of Education, Madawaska County - teachers 1901-1927, B8j4a, Carter to Hayes, 22 Sept. 1925. 
89 PANB, Correspondence of the Chief Superintendent of Education. Madawaska County - teachers 1901-1927. B8j4a, Savoie to Carter, 4 Dec. 1925. Emphasis in the original.

90 PANB, Correspondence of the Chief Superintendent of Education. Madawaska County - teachers 1901-1927. B8j4a, Carter to Savoie, 14 Dec. 1925.

91 Savoie, Memoires d'un Nationaliste Acadien, 105-06.

92 Ibid., 110.

93 Ibid, Wilbur, The Rise of French New Brunswick.

94 Savoie, Memoires d'un Nationaliste Acadien.

95 Wilbur, The Rise of French New Brunswick.

96 PANB, Correspondence of the Chief Superintendent of Education. Language, RS116 B2d, Calixte Savoie, to McFarlane, A.S., 21 Aug. 1933.

97 PANB, Correspondence of the Chief Superintendent of Education. Language, RS116 B2d, Carter to Dawson, 7 Jan. 1929.

98 Hody, "The Development of the Bilingual Schools of New Brunswick". For correspondence representing the protest movement, see PANB, Correspondence of the Chief Superintendent of Education. Language, RS116 B2d, Bulmer to Carter, 5 Feb. 1929, and PANB, Correspondence of the Chief Superintendent of Education. Language, RS116 B2d, Waitt to Carter, 18 Feb. 1929.

99 For evidence of Savoie's continued involvement in educational reform, see PANB, Correspondence of the Chief Superintendent of Education. Language, RS116 B2d, Carter to Savoie, 28 Sept. 1928, PANB, Correspondence of the Chief Superintendent of Education. Language, RS116 B2d, Savoie to McFarlane, 14 Aug. 1933, Théo Godin, "Les Origines De Lassociation Acadienne D'éducation: Notes Historiques Sur La Question Scolaire Au Nouveau-Brunswick," Revue d'histoire de l'Amérique française 5, no. 2 (1951): 186-192, and Savoie, Memoires d'un Nationaliste Acadien. For examples of Savoie's writing on educational issues in the 1930s, see Calixte F. Savoie, L'éducation des Petits Acadiens: Questions d'importance Vitale L'avenir de la Nationalité Acadienne (Edmundston NB: L'imprimierie du "Madawaska," 1934), and Le Système D'éducation au Nouveau-Brunswick (Moncton: La Société l'Assomption, 1938).

100 Clay Merrithew observes that the Byrne Commission was to all intents and purposes the blueprint for the Equal Opportunities Program, and that "education and finance were at the heart of Equal Opportunity." Merrithew, "The Educational Reforms of the Programme of Equal Opportunity (New Brunswick)," 5. 